\title{
Library Services and Availability of Information Resources in University Libraries, South-South Nigeria
}

\author{
Patience Owere Ekpang, Martina Ekpenyong Ekeng \\ Department of library and information science, University of calabar, calabar, Nigeria \\ Email: Martinaekeng001@gmail.com, p.ekpang@unical.edu.ng
}

(Received: December-2020; Reviewed: January-2021; Accepted: January-2021;

Avalaible Online: February-2021; Published: February-2021)

(7) (8) This is an open access article distributed under the Creative Commons Attribution License CC-BY-NC-4.0 (C2021 by author (https://creativecommons.org/licenses/by-nc/4.0/)

\begin{abstract}
This study investigated the relationship between library services and the availability of information resources in federal university libraries, in South-South, Nigeria. To achieve the purpose of this study, two research questions were raised and two hypotheses were formulated to guide the study. The ex-post facto research design was adopted for the study. The population of the study was 16620 students and a sample of 800 respondents was selected for the study. The selection was done through the stratified and purposive random sampling technique. The results of the analyses revealed a significant relationship between user education and preservation of information resources and availability of information resources. Based on these findings, it was recommended, among others that: User education should be adequately given to students to enable them to make the most use of the information resources and Government should prioritize funding for the preservation of information resources for university libraries.
\end{abstract}

Keywords: Library services; Availability; information Resources; Libraries and University

\section{INTRODUCTION}

In universities, libraries serve as the positive learning environment for all users in the academic community, to fulfill its mandate of supporting the teaching, learning and research activities of students, staff and other library users in the academic communities. Information resources refer to the numerous media by which information is recorded for students and scholars to help them meet their educational needs. In pursuit of their goals, these resources function as means that expose students to academic accomplishment. They are expected to support the curriculum and extra-curricular activities that positively contribute to their academic success. Students who depend on these information resources for all their curricula needs such as doing assignments, writing tests, writing term papers, seminars papers, and preparing for 
examinations are usually ahead of their counterparts who do not utilize the resources for further studies.

Students' success largely depends on the availability of information resources to be able to research within the shortest time. It helps them acquire knowledge for their academic pursuits and this is possible by exhaustive utilization of information resources. Therefore, when a library is well stocked with several categories of information resources the students will sufficiently utilize them (Awotola et al., 2018; Enidiok 2018). Availability of information resources has the potential of helping students make better academic achievements for further study. Furthermore, the availability of information resources for further studies turn-out to be better, more productive and outstanding in their academic achievements. Correspondingly, when there are no information resources available for further studies students often perform poorly in their academic work. They also turn out to be half-baked and sometimes incompetent when placed side by side with their counterparts. Therefore, the availability of information resources reduces mediocrity and brings academic excellence (Ekpang, 2011). When students make use of information resources, it complements lectures; provides students with knowledge for their academic quests and it is the secret of students' academic accomplishments.

As important as the availability of information resources is, it has been observed that students are not committed to utilizing these library information resources provided for them as expected. This signifies that their level of utilization is below expectation. This situation is seen in the low daily statistics of books consulted, books borrowed by students for home use, number of books photocopied by students, number of electronic database logins and reader services monthly statistics of library users. Clifford (2014) maintained that the problem of underutilization of information resources is a global one. Ekpang (2011) also observed that information resources were underutilized by students of tertiary institutions in Cross River State. This situation can be attributed to several factors which include inadequate user education on the availability of information resources and poor preservation of information resources.

When students come to the library for the first time, they surely do not know the activities of the library. They need to be through by the librarians on how to go about the whole process. User education is the basic instruction given to library users and students especially first-year students by librarians, on how to make effective use of information resources stored in the library to enable them to know where to find, and how to use the information resources in the library. When students come to the library for the first time, they do not know about various activities of the library. Through user education, library staff introduces students to their services, operations, rules and regulations. Effective user education programme helps to create a friendly atmosphere where students, librarians and information resources interact, thereby saving students' time; exposing them to alternative sources of information on a particular subject of interest; enabling them to make use of available information resources in the library. If user education is not given to students help them utilize library information resources profitably to meet their academic needs, this can discourage students from utilizing the information resources as they do not know how to locate nor use them (Watt and Ibegbulam, 2009).

Another responsibility of librarians is to preserve the acquired information resources to avoid deterioration, mutilation and loss of recorded knowledge. According to Aina (2007), preservation of information resources entails protecting the resources from destruction, to prolong their lifespan. In order to see that useful and relevant documents are not lost in large numbers of mutilated, worn-out and obsolete documents such documents are to be preserved to encourage maximum utilization by the students. Building and preserving information resources is necessary to encourage maximum utilization of such resources for the academic achievements of the students. When Librarians fail to preserve the information resources, they get mutilated 
leading to loss of recorded knowledge and complete abandonment of such information resources hence, the problem of underutilization. Appreciating the importance of information resources in the federal university libraries, the Federal Government of Nigeria through the National Universities Commission (NUC) occasionally intervenes in universities by stocking their libraries with information resources and other library facilities for students to utilize while in school. Also, different bodies like the Mac-Arthur Foundation Journal Donation Project Consortium provide access to millions of digital documents including video and multi-media resources to some universities. Nwachukwu, Abdulsalami and Salami (2014) opine that utilization of information resources refers to the extent to which students make use of the resources of a library to meet their information needs. Also, Ukih (2012) sees utilization of information as using the library resources. This justifies the purpose of establishing academic libraries in federal universities

\section{Statement of the problem}

In an attempt to address the problem of the availability of information resources in federal university libraries, certain variables such as user education and preservation of information resources have been considered to affect the utilization of information resources by students. It is on this premise that the researcher attempts to find out whether library services related to the availability of information resources in university libraries in South-South, Nigeria. The purpose of this study was to investigate how library services can relate to the availability of information resources in university libraries in South-south, Nigeria.

\section{Hypotheses}

1. User education has no significant relationship with the availability of information resources.

2. Preservation of information resources has no significant relationship with the availability of information resources.

\section{METHOD}

This study adopted an ex-post facto design. This research was carried out in south Nigeria. The targeted population of the study was the students who registered in their libraries in five federal universities in the south-south zone of Nigeria. A sample of eight hundred students who have registered in their libraries, from five federal university libraries namely, the University of Benin, University of Uyo, University of Port Harcourt, University of Calabar, University of Bayelsa. The sampling technique adopted for this study was the purposive sampling technique. The data collected were then analyzed using Pearson Product Moment Correlation.

\section{RESULT AND DISCUSSION}

\section{Results}

\section{Hypothesis 1}

The hypothesis tested that user education has no significant relationship with the availability of information resources in university libraries in the south-south zone of Nigeria. This was tested using Person product-moment correlation as presented in table 1 . 


\section{Table 1}

Person product-moment correlation showing the relationship between User education and availability of information resources

\begin{tabular}{lllll}
\hline Variables & $\overline{\mathrm{X}}$ & $\mathrm{SD}$ & $\mathrm{r}$-value & p-level \\
\hline User education & 15.24 & 3.21 & \multirow{2}{*}{$.348^{*}$} & .000 \\
Availability of information resources & 15.04 & 3.36 & & \\
\hline
\end{tabular}

*Significant at $\mathrm{p}$-value, $\mathrm{df}=798$

The independent variable in this hypothesis is user education while the dependent variable is the availability of information resources. To test this hypothesis, Person productmoment correlation analysis was employed. The result of the analysis is presented in Table 1. The result in Table 1 reveals that the calculated r-value of .348 is greater than the critical r-value of .088 at a .05 level of significance with 798 degrees of freedom. With this result, the null hypothesis was rejected. This result implies that user education has a significant relationship with the availability of information resources.

\section{Hypothesis 2}

The hypothesis tested that preservation of information resources does not significantly relate to the availability of information resources in university libraries in the south-south zone of Nigeria. This was tested using Person product-moment correlation as presented in table 2 .

Table 2

Person product-moment correlation showing the relationship between the preservation of information resources and availability of information resources

\begin{tabular}{lllll}
\hline Variables & $\overline{\mathrm{X}}$ & $\mathrm{SD}$ & r-value & p-level \\
\hline Preservation of information resources & 13.62 & 3.72 & & \\
& & & $.176^{*}$ & .000 \\
Utilization of information resources & 15.04 & 3.36 & & \\
\hline
\end{tabular}

*Significant at $\mathrm{p}$-value, $\mathrm{df}=798$

The independent variable in this hypothesis is the preservation of information resources while the dependent variable is the utilization of information resources. To test this hypothesis, Person product-moment correlation analysis was employed. The result of the analysis is presented in Table 2. The result in Table 2 reveals that the calculated r-value of .176 is greater than the critical r-value of .088 at a .05 level of significance with 798 degrees of freedom. With this result, the null hypothesis was rejected. This result implies that the selection of information resources does not significantly relate to the utilization of information resources.

\section{Discussion}

The first finding of this study indicates that User education of information resources has a significant relationship with the availability of information resources among registered students of federal universities libraries in south-south Nigeria. User education is a core activity of academic libraries that entails educating, enlightening, guiding and helping the students to identify, understand and utilize library information resources effectively. It provides students with the ability to utilize library facilities available to them independently and locate 
information resources provided with ease. The finding is in line with the view of Ode and Omokaro (2007) who opined that user education will not only help students to master the knowledge on how to use the library but also help them to become more independent in doing research. This study is inconsonant with Maduako (2013); Uwakwe, Oyeneke and Njoku (2016) who investigated the effect of user education on the law students' use of the library. They concluded that library instruction is an effective means of educating users and creating awareness of available information resources in the library.

The second finding of this study indicates that preservation of information resources has a significant relationship with the availability of information resources among registered students of federal universities libraries in south-south Nigeria. Information resources are preserved to ensure continuity of recorded knowledge and prevent loss of the same. This agrees with the view of Osayuwa-Odigie and Eneh (2010), who asserted that preservation of information resources in libraries prolongs the life of the resources. When information resources are welllooked-after and preserved, it makes them available to students to utilize them more in their learning and research activities. Also, the preservation of information resources allows outstanding information to be transferred from one generation to the other. Therefore adequate provision should be made available to preserve the information resources to ensure availability and use of such information resources in the future. The finding is in line with the view of Ogbodo (2011) who observed that dust and deterioration of books were the problems in the preservation of information resources. The researcher, therefore, recommended that libraries adopt modern technology to preserve the information resources. The findings of this study are also in line with Olatokun (2008) who stressed that preservation and conservation techniques, though adopted in the university libraries were not effective in use although the libraries all have preservation policies.

\section{CONCLUSION}

Based on these findings, it was concluded that users' education of information resources and preservation of information resources significantly relate to availability of information resources in the university libraries. This implies that where the users' education provided and information resources well preserved, there will be maximum availability of information resources by students in Nigerian universities.

\section{REFERENCES}

Aina, L.O. (2007). Library and information science test for Africa. Ibadan. StrilingHorden(Nigeria) publisher. Business Third World Information Services, Obafemi Awolowo University Press.

Awotola, U. C., \& Adewale, O. J. (2018). The Use of Academic Library Resources and Services by Undergraduate in Ibadan North Local Government of Nigeria. GNOSI: An Interdisciplinary Journal of Human Theory and Praxis, 1(2), 75-96.

Clifford, I. B. (2014). Availability, access to and level of use of academic library information resources; study of selected academic libraries in South-Western Nigeria. Availability, access to and level of use of academic library information resources; https://www.researchgate.net/publication/276294191.

Ekpang, P. O. (2011). Utilization of information resources and students' academic performance in tertiary institutions in Cross River State, Nigeria. Unpublished Masters Thesis in Library and information Science, University of Calabar in Faculty of Education. 
Enidiok, M. S., Bassey, A. B., \& Babatunde, A. A. (2018). Effect of Users Perception of Library Resources on Library Use: A Case Study of Faculty Libraries in the University of Ibadan. GNOSI: An Interdisciplinary Journal of Human Theory and Praxis, 1(1), 10-16.

Maduako, P. U. (2013). User education and library use in college of education in Abia and Imo States. Library Philosophy and Practice (e journal). Retrieved January 8, 2015 from http://digitalcommons.unl.edu/libphilprac/955 Nigeria University Commission (2010.) Annual Report.

Nwachukwu, V. N., Abdulsalami, T. L. \& Salami, P. F. (2014). Availability, accessibility and use of information resources and services among information seekers of Lafia Public Library in Nassarawa State. Information and Knowledge Management Journal, 4(10), 23 $-34$

Ode, E. O. \& Omokaro, O. A. (2007). Basic principles and practice of librarianship of Lagos library. The Information Manager, 15(2), 44-49.

Olatokun, W. M. (2008). A survey of preservation and conservation practices and techniques in Nigerian University libraries. Library and Information Science Research Electronic Journal, 18, 23-38.

Osayuwa-Odigie, H. T. \& Eneh, C. A. (2010). Non-book preservation techniques practiced in University of Benin and Delta State University libraries. 4108 http://digitalcommons.unl.edu/libphilprac/4108. Accessed 8/7/2017.

Ukih, M. M. O (2016). Utilization of library resources by lecturers in university of agriculture, Makurdi University of Jos. Nigerian Journal of Library Archival and Information Science, 1(5), 30-32.

Uwakwe, B. S., Onyeneke, C. O. \& Njoku, I. N. (2016). Effect of user education on law students' use of the library: A case of the faculty of law library, Imo state university, Owerri, Nigeria. Information Impact Journal of Information and Knowledge Management, 7(1), 70-85.

Watt, C. \& Ibegbulam, I. (2009). Access to electronic healthcare information resources in developing countries: Experience from medical library, college of medicine library, university of Nigeria: World library. 